regularity of solutions of the incompressible Navier-Stokes equation in 3 space dimensions. Although the full regularity of solutions is still unknown and likely very hard, Caffarelli-KohnNirenberg showed that the singular set must have parabolic Hausdorff dimension strictly less than one. In particular, singular fibers cannot occur. (V. Scheffer also deserves partial credit.)

Caffarelli has also produced deep work on homogenization and on equations with nonlocal dissipation. The list could be continued. Caffarelli is the world's leading expert on regularity of solutions of partial differential equations.

\section{Biographical Sketches}

Michael Aschbacher was born in 1944 in Little Rock, Arkansas. He received his B.S. from the California Institute of Technology in 1966 and his Ph.D. from the University of Wisconsin, Madison, in 1969. He joined the faculty of the California Institute of Technology in 1970 and is currently Shaler Arthur Hanisch Professor of Mathematics at Caltech. He was a visiting scholar at the Institute for Advanced Study in 1978-1979. He was awarded the Cole Prize in Algebra (1980), the Rolf Schock Prize of the Royal Swedish Academy of Sciences
(2011), and the Leroy P. Steele Prize for Mathematical Exposition (2012). He has been elected to the National Academy of Sciences (1990) and is a fellow of the American Academy of Arts and Sciences (1992) and of the American Mathematical Society (2012).

Luis Caffarelli was born in 1948 in Buenos Aires, Argentina. He received his Master of Science (1968) and Ph.D. (1972) degrees from the University of Buenos Aires. He has taught at the University of Minnesota, the University of Chicago, the Courant Institute of Mathematical Sciences at New York University, and the Institute for Advanced Study. He is currently the Sid W. Richardson Foundation Regents Chair in Mathematics at the University of Texas at Austin. He has received the Bôcher Memorial Prize (1984), the Rolf Schock Prize (2005), and the Leroy P. Steele Prize for Lifetime Achievement (2009). He is a member of the National Academy of Sciences (1991) and a fellow of the American Mathematical Society (2012).

\title{
Platonism Is the Law of the Land
}

\author{
David A. Edwards
}

It is a well-established principle of our legal tradition that mathematical formulas, laws of nature, and natural phenomena are not patentable subject matter. It is the purpose of this essay to argue that this tradition should be reversed. Our argument is that it is and always has been in our society's economic self-interest to grant very broad intellectual property rights. This is particularly important in our present Information Age where "software dominates."

The patent system is designed to promote the flow of technological innovation, a topic of much current concern in America. One often sees references to the relative decline in American vs. foreign patents as evidence of a decline in American innovation. But the main frontier of current technological innovation is in software, and software

David A. Edwards is associate professor of mathematics (retired) at the University of Georgia. His email address is dedwards@math.uga.edu.

DOI: http://dx.doi.org/10.1090/noti975 is not patentable. In fact the patent office itself has argued repeatedly against the patentability of software because it would be flooded with applications. ${ }^{1}$ This implies a very active software industry much desirous of patent protection.

At present, only those things which are made by man are patentable. Thus, the courts have allowed new forms of bacteria which have been engineered to have useful properties using recombinant DNA techniques to be patented but would not allow such a bacterium to be patented if it were naturally occurring even if it were newly discovered. This is the basis for the nonpatentability of computer programs. They are algorithms, which are essentially mathematical formulas, which-as everyone knows-are "eternal" and hence discovered by man and not created by him. This argument which,

${ }^{1}$ Harold T. Johnson Jr. Comment "Computer program patentability - the CCPA refuses to follow the lead of the Supreme Court in Parker v. Flook", North Carolina Law Review 58(1980), 319. 
to say the least, is philosophically controversial, leads to our present unfortunate policy. From an economic point of view, there is no rationale for distinguishing between discovery and invention, and we would advocate dropping entirely any subject matter restrictions whatsoever on what can be patented. One should be able to patent anything not previously known to man. In fact, a good economic case can be made ${ }^{2}$ for allowing the patenting of many things that are well known but are not being commercially produced.

The remainder of this essay is divided into three sections. In the first we discuss the historical background of the patent system. In the second we discuss the cases and laws which bear on subject matter patentability. In the last we summarize our position and provide further arguments in its favor.

\section{The Origins of Our Patent System}

All societies regulate economic behavior. This ranges from such extremes of regulation as found in ancient Egypt and modern Russia on the one hand to such relatively free-trade societies as Imperial Rome and nineteenth-century England on the other hand. However, there seems to be no evidence of intellectual property rights (patents, copyrights, and trademarks) in the ancient world. Such rights seem to have been systematically established for the first time during the late fifteenth century in Venice. ${ }^{3}$

In England, from which our traditions most immediately derive, the patent for new inventions evolved slowly out of a much more general policy of regulating and encouraging trade. As early as 1331, King Edward III was issuing letters patent (i.e., open, public) for the express purpose of encouraging new industry (in this case textiles) into the realm. ${ }^{4}$ These patents allowed foreign workers, with their knowledge of techniques not then known in England, to enter the realm and bypass the usual guild restrictions which applied to domestic workers. These policies were intensified during the reign of Queen Elizabeth as Lord Burleigh, the secretary of state, sought to make England self-sufficient, especially in those areas related to defense.

The English common law was strongly for free trade except for those circumstances which could be clearly shown to be in the general interest (e.g., defense). This tradition goes back at least as far as the Magna Carta. The famous Elizabethan jurist, Chief Justice Coke, in his influential treatise Institutes, defined a monopoly as "an institution or

\footnotetext{
${ }^{2}$ Edmund W. Kitch, "The nature and function of the patent system", The Journal of Law and Economics 265.

${ }^{3}$ B. W. Bugbee, Genesis of American Patent and Copyright Law, Public Affairs Press, 1967.

${ }^{4}$ Harold G. Fox, Monopolies and Patents, 1947.
}

allowance by the King, by his agents, commission, or otherwise, to any person or persons, bodies politic or corporate, of or for the sole buying, selling, making, working, or using anything; whereby any person or persons, bodies politic or corporate, are sought to be restrained of any freedom or liberty that they had before, or hindered in their lawful trade." ${ }^{\text {If }}$ such a restraint was to be legal, good reasons had to be forthcoming. Unfortunately, good reasons weren't always forthcoming. Abuses led to tensions between Parliament and the Crown, which culminated during the reign of Charles I. An acceptable good reason for a temporary monopoly was to promote new manufacturing. In this case the freedom that was constrained was not one that the persons were considered to have had before. One should note in particular that this included not only forms of manufacturing that were entirely new to mankind, but also forms that were only new to the realm.

Based upon the long experience in England and in the separate colonies, the framers of the U.S. Constitution unanimously adopted Article I, Section 8: "The Congress shall have the Power... To promote the Progress of Science and useful Arts, by securing for limited Times to Authors and Inventors the exclusive Right to their respective Writings and Discoveries." The Constitution does not have any subject matter restrictions. In fact, up to that time no patent had been declared invalid because of subject matter. ${ }^{6}$ But this almost happened (the court split 2-2) in the famous case of Boulton $v$. Bull (1795) to which we now turn.

\section{Subject Matter Patentability}

The case of Bolton and Watt against Bull seems to be the first case in which the validity of a patent was questioned because of its subject matter. The first commercially successful steam engine was developed by Newcomen in the early eighteenth century. ${ }^{7}$ In the middle of the century Smeaton performed a series of painstaking Baconian studies on the Newcomen engine and managed to roughly double its efficiency. Watt's approach was much more theoretical and resulted not in small evolutionary changes, but instead in the revolutionary change of using two cylinders instead of one. Watt's patent starts as follows: "My method of lessening the consumption of steam, and consequently fuel in fire engines, consists of the following principles." He goes on to describe his new principles, which would today be called the laws of thermodynamics. These principles were first abstractly treated by Sadi Carnot several decades later.

\footnotetext{
${ }^{5}$ Co. 3 Inst. 181, C. 85. Quoted in Fox, p. 8.

${ }^{6}$ Fox, p. 234.

${ }^{7}$ The development of the steam engine is very clearly discussed in D. S. L. Cardwell, Turning Points in Western Technology, 1972.
} 
Watt was asking for a patent not merely for a new steam engine with a specific new design, but instead for a whole new class of possible new steam engines whose designs were not described explicitly but were instead described by Watt's higher-level principles. He was not asking for a patent on these principles themselves in the sense that anyone desiring to use or describe these principles would have to get his permission and possibly pay him royalties, but only for a patent on steam engines designed according to these principles. All four judges agreed that one couldn't get a patent for the principles themselves. However, the judges split 2-2 on the question of Watt's patent itself; two of them felt that its scope was much too broad, while the other two felt that the principles were acceptably being used to adequately describe Watt's innovations in steam engine design.

Similar situations arose throughout the nineteenth century. (See, for instance, O'Reilly $v$. Morse. ${ }^{8}$ ) A twentieth-century case in which the issues are particularly clearly drawn is the case of MacKay Radio and Tel. Co. v. Radio Corp. of America. ${ }^{9}$ Radio Corporation of America (RCA) had a patent for an antenna whose structure was described using a mathematical formula. The court held the patent valid as not being on the formula itself but instead on the antenna. The court stated that "[w]hile a scientific truth, or the mathematical expression of it, is not a patentable invention, a novel and useful structure created with the aid of knowledge of scientific truth may be."

Computer software presents a problem area where, as the Supreme Court has recently put it, “[t]he line between a patentable 'process' and an unpatentable 'principle' does not always shimmer with clarity." ${ }^{10}$ In In re Bernhart, ${ }^{11}$ the Court of Customs and Patent Appeals (C.C.P.A.) stated:

[I]f a machine is programmed in a certain new and unobvious way, it is physically different from the machine without that program; its memory elements are differently arranged. The fact that these physical changes are invisible to the eye should not tempt us to conclude that the machine has not been changed. If a new machine has not been invented, certainly a "new and useful improvement" of the unprogrammed machine has been, and Congress has said in 35 U.S.C. \#101 that such improvements are statutory subject matter for a patent.

This argument of the C.C.P.A. would have extended patent protection to all uses of algorithms in computers, but not to other uses of algorithms (such as human use). Unfortunately, this argument was overturned by the Supreme Court

\footnotetext{
${ }^{8} 56$ U.S. (15 How.) 62 (1853).

9306 U.S. 86 (1939).

10437 U.S. 584 (1978).

${ }^{11} 417$ F. $2 d 1395$ (C.C.P.A. 1969).
}

in Gottshalk v. Benson. ${ }^{12}$ Until 1990 software had only copyright protection. This is adequate protection only for software containing no new ideas, as copyright protects only the expression in a work and not the ideas in it. (See Baker v. Selden. ${ }^{13}$ )

Around 1990 the courts "found" a way to protect software via the patent system. They also allowed business methods and many areas of bio-tech. But more recently the issue has resurfaced in Bilski. There is no economic basis for the distinction between discovery and invention. If we're going to have a general patent system, then algorithms should be as patentable as lasers. For example, general relativity is used in GPS (see http://en.wikipedia.org/wiki/Global_ Positioning_System). My colleague Carl Pomerance developed fast primality testing algorithms in the late 1970s but couldn't patent them. My colleague Victor Wickerhauser developed the fast wavelet transform in the early 1990s and was able to patent it as a software patent. I believe the recent rulings (see http://www. nytimes.com/2010/03/31/nyregion/31about. htm1?sq=inventions\%20and\%20patents\& st $=$ cse\&scp $=2 \&$ pagewanted $=p r i n t$ and http://www.nytimes.com/2010/10/30/ business/30drug.htm 1 ? r $=1 \&$ hp $=\&$ pagewanted=print) were correct current law and will end up also invalidating software patents. If we want these things to be patentable, then Congress needs to change the law.

\section{Conclusions}

For the past two hundred years all our courts and legislatures have unanimously ruled that mathematical formulas, laws of nature, and natural phenomena are not patentable subject matter. A typical rationale for these rulings is the following footnote which occurs in the Supreme Court's recent opinion in the case of Parker v. Flook: ${ }^{14}$

The underlying notion is that a scientific principle, such as that expressed in respondent's algorithm, reveals a relationship that has always existed.

"An example of such a discovery [of a scientific principle] was Newton's formulation of the law of universal gravitation, relating the force of attraction between two bodies, $F$, to their masses, $m$ and $m^{\prime}$, and the square of the distance, $d$, between their centers, according to the equation $F=\mathrm{mm}^{\prime} / \mathrm{d}^{2}$. But this relationship always existed-even before Newton announced his celebrated law. Such 'mere' recognition of a theretofore existing phenomenon or relationship carries with it no rights to exclude others from its enjoyment... Patentable subject matter must be new (novel); not merely heretofore

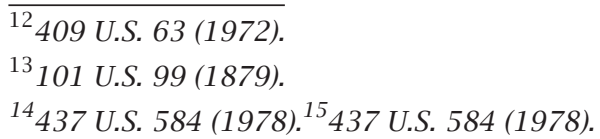




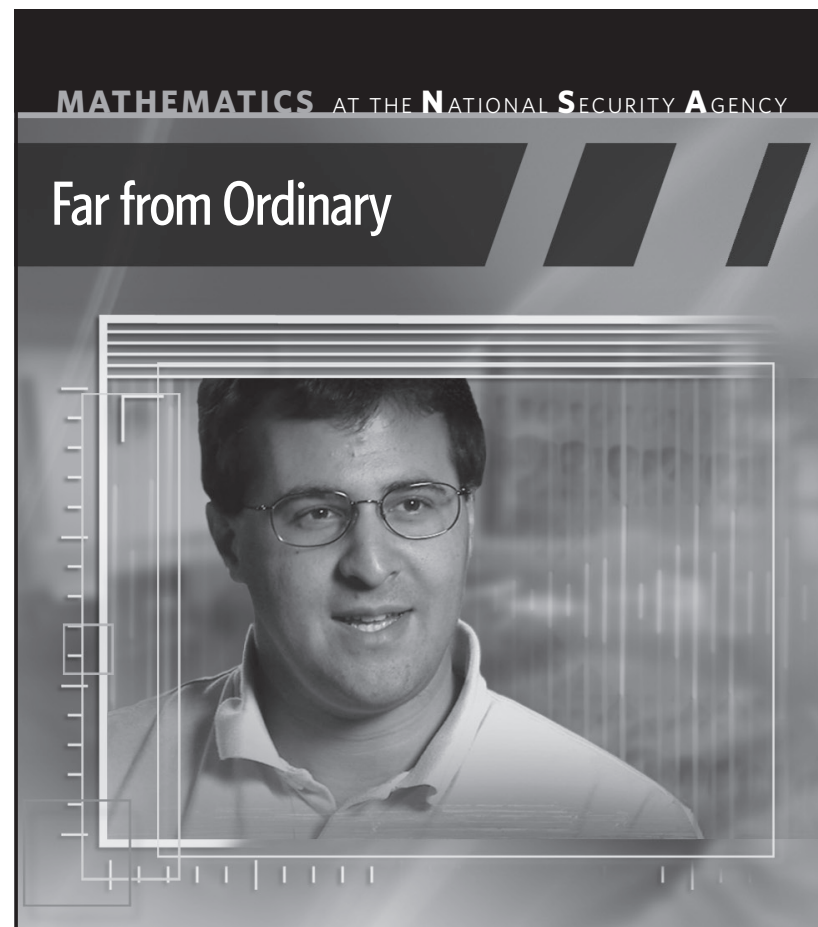

unknown. There is a compelling reason for this rule. The reason is founded upon the proposition that in granting patent rights, the public must not be deprived of any rights that it theretofore freely enjoyed." P. Rosenberg, Patent Law Fundamentals, \#4, at 13(1975).

This "very compelling reason" goes back to Cooke (see quote in \#1) but is taken totally out of context. Cooke would not have considered the public to have been enjoying rights to unknown things. This line of argument could be pushed to void all patents.

Up until recently, the economic consequences of these restrictions in intellectual property rights have probably been quite slight. Similarly, the economic consequences of allowing patents for new inventions were also probably quite slight up to about 1800 . Until then, patents were mainly import franchises. After 1800 the economic consequences of allowing patents for new inventions became immense as our society moved from a predominately agricultural stage into a predominately industrial stage. Since the end of World War II,our society has

The U.S. is under cyber attack, every minute of every day. That's why cyberspace has become today's new front line. What you know can make a difference at the National Security Agency. Whether it's collecting foreign intelligence or preventing foreign adversaries from accessing U.S. secrets, you can protect the nation by putting your intelligence to work. Explore technology that's years ahead of the private sector. Plus exciting career fields, paid internships, co-op and scholarship opportunities. See how you can be a part of our tradition of excellence and help the nation stay a step ahead of the cyber threat.

\section{KNOWINGMATTERS}

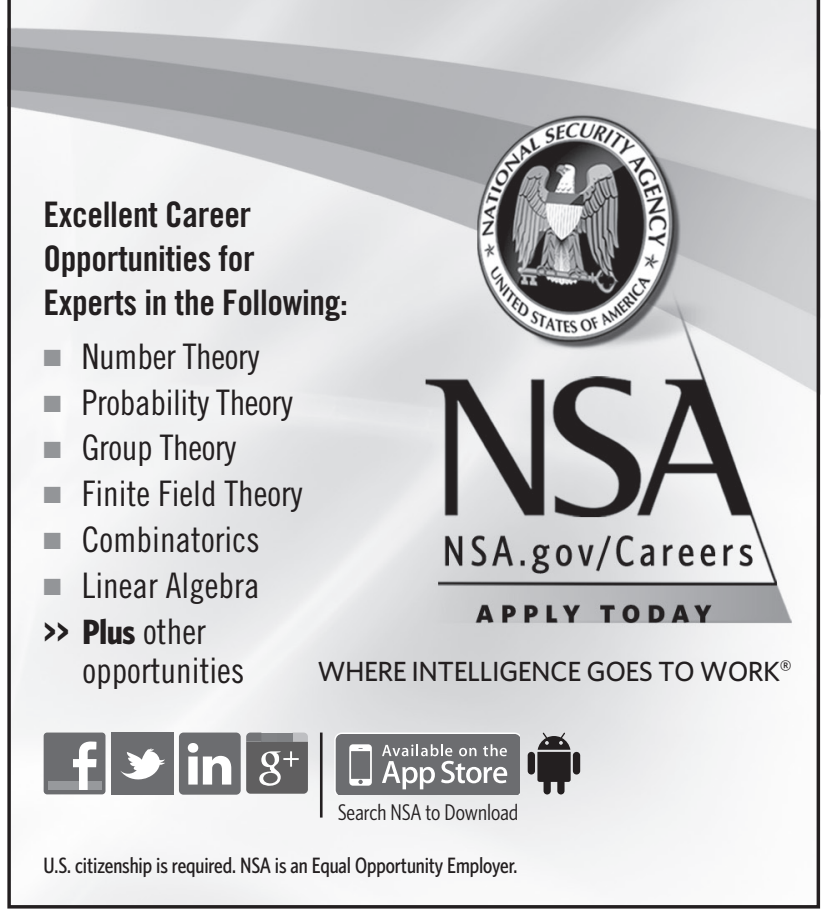

been moving into an information stage, and it is becoming more and more important to have property rights appropriate to this stage. We believe that this would best be accomplished by Congress amending the patent laws to allow anything not previously known to man to be patented.

More specifically, the distinction between discovery and invention should be eliminated. This would allow the patent incentive to motivate exploration for previously unknown useful forms of bacteria, plants, animals, materials, molecules, atoms, particles, etc. Previously unknown mathematical formulas and laws of nature should also be patentable. Since patents only give control over the commercial applications of his or her discovery or invention to the patentee, granting patents on mathematical formulas, laws of nature, and natural phenomena would have no negative side effects on pure science. The economic stimulation of pure science that would be provided by such patents is particularly important today as the traditional economic support of pure science, namely university faculty positions and government grants, are in decline. For the society as a whole, the positive economic effects of such extended intellectual property rights would be quite substantial. Today's technology depends upon yesterday's science.

In conclusion, it is time for Congress to update the patent laws and provide for the appropriate intellectual property protection which our age demands.

\section{Additional References}

1. D. S. Chisum, Intellectual Property: Copyright, Patent and Trademark Law, Mathew Bender, N.Y., 1980.

2. E. W. Kitch and H. S. PeRlman, Legal Regulation of the Competitive Process, The Foundation Press, Inc., N.Y., 1979. 